\title{
Endogeneity of money: The case of Czech Republic
}

\author{
Liběna Černohorská \\ Faculty of Economics and Administration, University of Pardubice \\ Crech Republic \\ libena.cernohorska@upce.cr.
}

Abstract. The goal of this paper is to specify the trends of money supply in Czech Republic. This will allow us evaluate the current approach taken by the Czech National Bank in its monetary policy. To determine money's endogeneity, we have analyzed time series for the M3 monetary aggregate, the monetary base, GDP, and loans. As part of the analysis, we have worked with quarterly data from the $1^{\text {st }}$ quarter of 1996 to the $2^{\text {nd }}$ quarter of 2017 . We determined the optimal lag time for the time series using the Hannan-Quinn information criterion. Next, we have analyzed the stationarity of the time series using the Dickey-Fuller test. We have further tested the stationary time series with the $8330.2018 / 11-4 / 11$ Engle-Granger test. Testing long-term relationships using the Engle-Granger cointegration test between the money supply (expressed by the M3 monetary aggregate) and both GDP and loans, and then between the money base and loans did not confirm long-term relationships between the values examined. Therefore, we can consider the money supply in Czech Republic to be endogenous. Two-way causal relationships between M3 and both GDP and loans as well as between the monetary base and loans was confirmed using the results of Granger causality testing as a basis.

Keywords: Czech Republic, endogeneity of money, GDP, Granger causality test, M3, money base.

JEL Classification: E51, E47, C32

\section{INTRODUCTION}

Central banks are seen as monetary authorities that play an irreplaceable role in implementing monetary policy and regulating financial markets as well as also influencing economic development in market economies. Implementing monetary policy has become one of the defining characteristics of central banks. Currently, in market economies, issuing money is limited by regulatory measures, which concern adherence to rules for cautious business dealings, e.g., the requirement of maintaining capital adequacy, rules of engagement, or meeting qualification limits for bank involvement with other entities. Even despite these measures, constant increase in the amount of money has been seen for individual 
economies in recent decades, which subsequently affects other economic variables, such as the price level or economic growth.

From the historical perspective, arguments over money's endogeneity or exogeneity can be divided into two groups. The orthodox school of thought starts with monetary theory based on the quantity theory of money; as it has been addressed in economic literature, possibly only with the exception of (Howells \& Bain, 2009). The process of creating money is based on the operations of a money multiplier. If there is a constant money multiplier, the central bank can effectively control money supply. At the same time, the central bank also influences the volume of loans awarded by using its instruments. The unorthodox faction approaches money entirely differently - it understands the money supply to be endogenous, where it is determined by the overall economic need for loans within the economic system. The main starting point for this theory is the fact that central banks can effectively influence the interest rate.

This paper's primary goal is to investigate the nature of the process of money provision in connection with a discussion of the concept of exogenous or endogenous money supply in Czech Republic from 1996 to 2017. For expressing the nature of money in Czech Republic, we will start with one-way or two-way causal relationships between the M3 monetary aggregate and both GDP and bank loans provided by the private non-financial sector (hereinafter only loans) - as well as between the money base (MB) and loans. If endogenous money supply is confirmed, we will then determine the theoretical concept which it most resembles (accommodationist, structuralist, or Keynesian liquidity preference).

\section{LITERATURE REVIEW}

Above all, discussion of money's endogeneity or exogeneity begins with the debate on monetary policy in Great Britain during the first half of the $19^{\text {th }}$ century. A whole range of economists were influenced by this debate, primarily Knut Wicksell and, in his wake, John M. Keynes, who proposed the unorthodox approach to the theory of money. Mainstream post-war economics, led by John Hicks and Alvin Hansen, is based on the concept of an exogenous money supply. Monetarists and proponents of classical macroeconomics renounced the idea of an exogenous money supply. The post-Keynesians subsequently developed the endogenous money supply (Koderová et al., 2008).

The endogenous theory of money tries to find the ties between money and economic activity in individual economies. Fontana (2002) considers the essence of the endogenous theory of money to be the post-Keynesians' mutual relationship between the financial and the real sectors, where the money supply is determined by demand for bank loans, which arises from the necessity of securing financing for manufacturing and speculative activities, which means that money is determined by the size of the demand for loans.

Monetarists understand the money supply to be exogenous just as Keynesians do. Monetarists start with a one-way causality for both the money supply and the money base regarding loans as well as with one-way causality for the money supply and GDP. Post-Keynesians state that the money supply is determined endogenously via decision making concerning assets and liabilities on the part of banks, the non-bank public, and the demand for bank loans (Palley, 1994). The causal relationship encompasses banks providing loans and thus affecting bank deposits, instead of the traditional conception of deposits creating loans. Despite the fact that proponents of post-Keynesian theory accept the basic tenants of an endogenous concept of money, there are certain differences between them. Accommodationists, structuralists, and proponents of liquidity preference comprehend the relationship between the money supply and bank loans in different ways. Accommodationists also observe that loans have a one-way causal relationship with the money base and the money supply, whereas they observe two-way causal 
relationships for GDP and the money supply. Certain authors (e.g., Borio (1997) and Haghighat (2011)) also monitor the causality of changes in GDP regarding the money supply, which changes in the money base as a final result. Accommodationists assume the following relationships: a one-way causal relationship between loans and the monetary base or the money supply, which is satisfied when the demand for reserves is fully met by the central bank. Furthermore, they also observe two-way causal relationships between real GDP and the money supply. Two-way causal relationships are examined by structuralists, either concerning loans and the money base or the money supply - or GDP and the money supply. According to endogenous claims, there exists a two-way causal relationship between the money supply and economic activity. In contrast to the accommodationists, the structuralists assert that banks do not entirely satisfy the demand for loans (Palley, 1996). Next, Keynesian liquidity preference assumes twoway causal relationships between loans and the money supply. Supporters of liquidity preference agree with the core tenants of the endogeneity of money but also acknowledge that specific discrepancies exist between the accommodationists and structuralists. Their approach also supports the core of the accommodationists' theoretical arguments in favor of an endogenously established money supply. The main criticism faced by the opinion supporting liquidity preference is derived from the accommodationist assumption that there is no "excessive" offering of loan money, which means that there is no independent demand for money in operation (Howells, 1997 or Palley, 1991). Liquidity preference predicts causality in overall bank loans affecting the money supply, if the money supply has been established endogenously.

Table 1

The endogenous theory of money

\begin{tabular}{|l|l|l|}
\hline \multicolumn{1}{|c|}{ Accommodationists } & \multicolumn{1}{c|}{ Structuralists } & \multicolumn{1}{c|}{ Keynesian liquidity preference } \\
\hline loans $\rightarrow$ money base & loans $\leftrightarrow$ money base & loans $\leftrightarrow$ money supply \\
\hline loans $\rightarrow$ money supply & GDP $\leftrightarrow$ money supply & \\
\hline GDP $\leftrightarrow$ money supply & & \\
\hline
\end{tabular}

Source: Processed by Palley (1996, 1998), Pollin (1991), Moore (1998), Howells (1997).

Table 1 depicts the theoretical definitions of the individual causal relationships in an endogenous money supply. We have compared the results from the time series analysis in Section 4 with the one- or two-way causal relationships listed in Table 1 and then determined the approach to the money supply in the Czech Republic based on the causal relationships that were revealed.

Many authors (e.g., Arestis \& Sawyer (2006); Chick \& Dow (2002); Kaldor (1970); \& Fontana (2002)) have dealt with the current issues around the relationship of the endogenous theory of money and monetary policy. The study by Arestis and Sawyer (2006) deals with how to conduct monetary policy and the role it plays when money is created in the form of endogenous money in the private sector.

Using Granger causality tests, Pollin (1991) established a structuralist approach to endogenous money for data from the USA for the years 1953 to 1988. Vera (2001) came to the conclusion, based on Granger causality tests, that Spain had an endogenous money supply during the years 1987 to 1998, which supports the accommodationist and structuralist approaches. Using an error correction model and Granger causality testing, Shanmugan, Nair, and Li (2003) investigated the relationship between the monetary base, loans, and the industrial production index in Malaysia for the years 1985 to 2000; they came to the conclusion that they support the accommodationist and liquidity preference approaches to endogenous money. Ahmad and Ahmet (2006) conducted short- and long-term tests of money supply endogeneity in Pakistan from 1980 to 2003 using the Granger causality test. The empirical conclusions support the structuralist and preference theories. Badarudin et al. (2012) tested for an endogenous money supply in 
Australia for the years 1977 to 1993 . The authors determined that loans affect the money supply. They used the Granger causality test for their analysis. Using panel data analysis, Nayan et al. (2013) dealt with the nature of the money supply in 177 countries for the years 1970 to 2011. The authors concluded that the money supply is endogenous, as asserted by the post-Keynesians. On the basis of research, it is clear that monetary authorities consider the money supply to be endogenous. If the money supply in the countries examined is endogenous, the use of monetary policy can be considered to be appropriate and effective.

\section{DATA AND METHODOLOGY}

\subsection{Data}

We conducted this analysis in the Czech Republic for the variables of the M3 monetary aggregate (M3), the money base (MB), real GDP, and bank loans provided to the private nonfinancial sector (hereinafter only loans or CRED). The time series that we used summarize quarterly data from the period of the 1st quarter of 1996 through to the 2 nd quarter of 2017. Overall, this covers 86 observations. All the data have been cleaned from seasonal influence. We obtained the data on GDP from Eurostat's statistics (Eurostat 2017a; Eurostat 2017b), the evolution of the M3 monetary aggregate was obtained from the OECD (OECD, 2017), and we derived the size of loans from the statistics of the Bank for International Settlements (BIS, 2017). We conducted the statistical analysis using the econometric analysis program Gretl 1.9.4.

We performed a logarithmic transformation on the time series in order to obtain a log-normal distribution for the time series. The time series that have undergone logarithmic transformation are labeled 1_M3_CZE, 1_GDP_CZE, etc. As part of the ADF tests and testing for Granger causality, we worked with time series for which we had conducted differencing. For the first differences, we have labeled these time series as d_l_M3_CZE, d_l_GDP_CZE, etc.

\subsection{Methodology}

For the time series analyses, we first need to determine the optimal lag time and if the data being analyzed are stationary. Optimal lag time is determined using information criteria, which always involves searching for the lowest information criteria value, which is then used in the next approach. The time series' stationarity is determined by conducting an ADF test. If the null hypothesis is not rejected, the time series are nonstationary. Next, the time series are modified using differencing, and an ADF test is conducted once more. If the differences of time series modified in this way are stationary, an actual EngleGranger test is conducted. This is used to establish whether or not there is a cointegration relationship between the time series. At the same time, whether there are long-term relationships between the economic variables is determined. For mutual causality in the causal relationships between the variables, Granger causality testing is conducted for the cases where the time series were not cointegrated.

First, we determine the optimal lag length for the dependent variables. Information criteria are used to determine optimal lag length: the Akaike information criterion (AIC), the Bayes information criterion (BIC), and the Hannan-Quinn information criterion (HQC). When analyzing time series, one looks for the lowest value of the selected information criteria (Černohorský, 2017). The lag length is determined according to where the lowest information criterion value is located. Lag lengths determined in this way are subsequently used in further testing. The appropriate criterion depends on the number of observations. As Liew (2004) and Gottschalk (2000) state, it is appropriate to use the AIC or its 
alternative, the BIC, for determining optimal lag length when there is a low number of observations (lower than 60). The HQC is most often used when the number of observations is greater and for quarterly data; therefore, we will proceed with this information criterion. In 1979, two Australian statisticians, Hannan and Quinn (1979), presented another criterion, the Hannan-Quinn information criterion.

$$
H Q C=n * \ln \left(\frac{R S S}{n}\right)+2 k c l n
$$

where RSS is residual sum of squares; $\mathrm{k}$ is the number of parameters, $\mathrm{n}$ is the number of measurements; $\mathrm{c}$ is the additive constant; and $\mathrm{RSS} / \mathrm{n}$ is residual variance.

After determining optimal lag length, conducting the augmented Dickey-Fuller test (hereinafter the ADF test) follows. When verifying the ADF test hypotheses, we used the basic test types (with a constant and with a constant and a trend). The following equation is used when testing; its use determines if the variable contains a unit root, i.e., if $\varnothing=0$.

$$
\Delta y_{t}=\emptyset y_{t-1}+\sum_{i=1}^{p} \alpha_{1} \Delta y_{t-i}+\varepsilon_{t}
$$

where: $\mathrm{y}_{\mathrm{t}}$ is the dependent variable; $\mathrm{p}$ is lag; and $\varepsilon_{t}$ is the residual component.

Verifying the null hypothesis regarding stationarity is conducted using the $p$-value, which is compared to $a$ (the level of significance). We will use a level of significance of 0.05 for the tests being conducted. If there is an ADF test, the hypotheses will be set as follows:

- $\mathrm{H}_{0}$ : the time series are nonstationary;

- $\mathrm{H}_{1}$ : the time series are stationary

But, if the $p$-value is lower than the level of significance, we reject the null hypothesis and can confirm that the time series are stationary. If the time series are nonstationary, we must modify the original time series using differencing (we create the first difference) and test the new data again for stationarity.

If trends of a stochastic nature occur, it is possible to substitute the original data with their differences. If the first differences $\Delta Y_{t}$ are stationary, then $Y_{t}$ has a unit root. The Granger concept of cointegration is based on observing the statistical characteristics of linear combinations of two integrated variables. It is possible to present a regression model, which is a specific time series model, in the following way:

$$
Y_{t}=\beta X_{t}+u_{t}, t=1,2, \ldots, T
$$

where: $Y_{t}, X_{t}$ are variables, $\beta$ is the cointegrating parameter, and $u_{t}$ is deviation from equilibrium.

If both variables $Y_{t}, X_{t}$ are integrated and if there is the existence of a non-null parameter $\beta$, their linear combination is stationary:

$$
u_{t}=Y_{t}-\beta X_{t}
$$

where $Y_{t}$ and $X_{t}$ can be called cointegrated variables.

Cointegration analysis, i.e., the Engle-Granger test, was designed by Engle and Granger (1987). The Engle-Granger test (the EG test) investigates the existence of a unit root. We have established the following hypotheses for this test: 
- $\mathrm{H}_{0}$ : the time series are not cointegrated;

- $\mathrm{H}_{1}$ : the time series are cointegrated.

Making decisions about the relationship of the time series is derived from the $p$-value defined by the Engle-Granger cointegration test. If the null hypothesis is not rejected ( $p>0.05)$, the time series will be labeled noncointegrated, i.e., containing a unit root. In the opposite case $(p<0.05)$, the time series will be labeled cointegrated, i.e., they do not contain a unit root.

The concept of causality, which was introduced by Granger (1969) and Sims (1972), is used in econometric analysis. Whether the investigated variables are endogenous can be tracked in the simplified two-equation model. The reason for testing causal relationships (i.e., causality) according to Granger's definition is to determine whether specific variables' changes come before the changes of other variables. It does not determine which variable is causal and which is an effect.

If $Y_{2}$ determines $Y_{1}$, then it is true in Granger causality that $Y_{2}$ 's changes came before $Y_{1}$ 's changes while meeting the following criteria (Hušek, 2007):

- The lagged value of the variable $Y_{2}$ is involved in greater precision in the prediction of $Y_{1}$.

- The variable $Y_{1}$ does not have an influence on increasing the precision in predicting $Y_{2}$.

Granger (1969) proposed a simple testing procedure for verifying the validity of the two conditions listed above, which are derived from the VAR models. It is possible to write so-called unlimited regression for testing the hypotheses:

- $\mathrm{H}_{0}$ : the variable $X_{t}$ does not affect the variable $Y_{t}$ according to Granger's definition;

- $\mathrm{H}_{1}$ : the variable $X_{t}$ affects the variable $Y_{t}$ according to Granger's definition in the following way (Hušek, 2007):

$$
Y_{t}=\sum_{i=1}^{p} \alpha_{i} Y_{i-r}+\sum_{i=1}^{p} \beta_{i} X_{t-i}+u_{t}
$$

where: $\beta_{i}$ is the parameter, $u_{t}$ is random error (residual) and where it is possible to set the maximum lag of $p$ at an arbitrary length.

If the coefficients $\beta_{i}=0(i=1,2, \ldots, p)$, then the variable $X_{t}$ does not fit the prerequisites for Granger causality.

\section{RESULTS AND DISCUSSION}

\subsection{Testing for optimal lag length using the HQC}

The first analysis investigates the influence of M3 monetary aggregate, monetary base on the development of the GDP and credits in the Czech Republic. On the basis of the theoretical model, the first prerequisite before determining the time series' cointegration is the test verifying optimal lag length. The optimal lag length is determined using information criteria in a dynamic regression equation. The HQC were used for the dependent variable to determine optimal lag. It is necessary to test the time series for optimal lag before using the EG test, where the dependent variables are the value of GDP and credits. Table 2 lists the values of the HIC criterion for 6 lag lengths (the lowest value is always shown in bold type). On the basis of the lowest value found for the information criterion, an optimal lag length of six is specified for the dependent variables of the GDP and credits, which were determined for the HQC. This lag will be taken into consideration in the subsequent tests. 
Test Results for Optimal Lag by HQC for M3 and MB - Test with Constant

\begin{tabular}{|c|c|c|c|c|c|c|}
\hline \multirow{2}{*}{$\begin{array}{c}\text { Order of } \\
\text { lag }\end{array}$} & \multicolumn{2}{|c|}{ Test with constant } & \multicolumn{3}{c|}{ Test with constant and trend } \\
\cline { 2 - 7 } & 1_GDP_CZE & 1_CRED_CZE & 1_CRED_CZE & 1_GDP_CZE & 1_CRED_CZE & 1_CRED_CZE \\
\cline { 2 - 7 } & $-6,572627$ & $-2,316867$ & $-2,32001$ & $-6,782997$ & $-2,283297$ & $-2,28045$ \\
\hline 1 & $-7,255967$ & $-2,31499$ & $-2,31717$ & $-7,295477$ & $-2,26934$ & $-2,282965$ \\
\hline 2 & $-7,228149$ & $-2,28784$ & $-2,2896$ & $-7,270727$ & $-2,24137$ & $-2,26003$ \\
\hline 3 & $-7,219818$ & $-2,25197$ & $-2,25361$ & $-7,262875$ & $-2,20575$ & $-2,22437$ \\
\hline 4 & $-7,186823$ & $-2,2308$ & $-2,23215$ & $-7,228531$ & $-2,18754$ & $-2,20575$ \\
\hline 5 & $-7,162351$ & $-2,23082$ & $-2,23073$ & $-7,203161$ & $-2,19404$ & $-2,20744$ \\
\hline 6 & & & & & & 1_M3_CZE \\
\hline
\end{tabular}

Source: Authors' calculations in Gretl 1.9.4

\subsection{Verifying the Stationarity of the Time Series - ADF test}

Possible non-stationarity of data can lead to apparent regression; the difficulty with this lies mainly in the fact that using the least squares method would make it possible to obtain statistically significant parameter estimates of the regression function - even though the time series analyzed do not relate to each other. For this reason, it is necessary to test the time series used here with the help of an augmented Dickey-Fuller test. The results of the ADF test for a unit root are shown in Table 3 (where all p-values for each parameter of the variables analyzed are displayed successively).

The model with a constant or with a constant and a trend enters into the ADF test in conjunction with the results of the testing for the optimal lag length, i.e., the minimum HQC value (4.1). As part of the ADF test, we tested time series 1_M3_CZE and 1_GDP_CZ for two lag lengths and a test with a constant and a trend, 1_M3_CZE and 1_CRED_CZE for one lag length and a test with a constant, and time series 1_MB_CZE and 1_CRED_CZE for one lag length and a test with a constant.

Table 3

The Results of the Augmented ADF Test for a Unit Root

\begin{tabular}{|l|c|c|c|}
\hline \multicolumn{1}{|c|}{ Time series } & Value of $p$ - parameter & Evaluation of ADF test results & $\mathrm{H}_{0}:$ \\
\hline 1_M3_CZE & 0,5981 & Time series non-stationary & Not refused \\
\hline 1_GDP_CZE & 0,563 & Time series non-stationary & Not refused \\
\hline 1_M3_CZE & 0,9698 & Time series non-stationary & Not refused \\
\hline 1_CRED_CZE & 0,9284 & Time series non-stationary & Not refused \\
\hline 1_MB_CZE & 0,9879 & Time series non-stationary & Not refused \\
\hline 1_CRED_CZE & 0,3296 & Time series non-stationary & Not refused \\
\hline
\end{tabular}

Source: Authors' calculations in Gretl 1.9.4

Figure 1 depicts the courses of individual time series MB, GDP, M3, and loans in the CR after logarithmic transformation.

As can be seen here, for time series with absolute values, all time series at a significance level of 0,05 were marked as non-stationary. Nonstationarity of the time series means that illusory correlation could 
occur when conducting correlation analysis. Stationarity for all the time series was achieved only after they had been differenced (Table 4).

Table 4

The Results of the Augmented ADF Test for a Unit Root - First Difference

\begin{tabular}{|l|c|c|c|}
\hline \multicolumn{1}{|c|}{ Time series } & Value of $p$ - parameter & Evaluation of ADF test results & $\mathrm{H}_{0}:$ \\
\hline d_l_M3_CZE & 0,0002333 & Time series stationary & Refused \\
\hline d_l_GDP_CZE & 0,2212 & Time series non-stationary & Not refused \\
\hline d_l_M3_CZE & $1,055 \mathrm{e}-006$ & Time series stationary & Refused \\
\hline d_1_CRED_CZE & $7,49 \mathrm{e}-006$ & Time series non-stationary & Not refused \\
\hline d_1_MB_CZE & $1,158 \mathrm{e}-014$ & Time series stationary & Refused \\
\hline d_1_CRED_CZE & $7,49 \mathrm{e}-006$ & Time series stationary & Refused \\
\hline
\end{tabular}

Source: Authors' calculations in Gretl 1.9.4
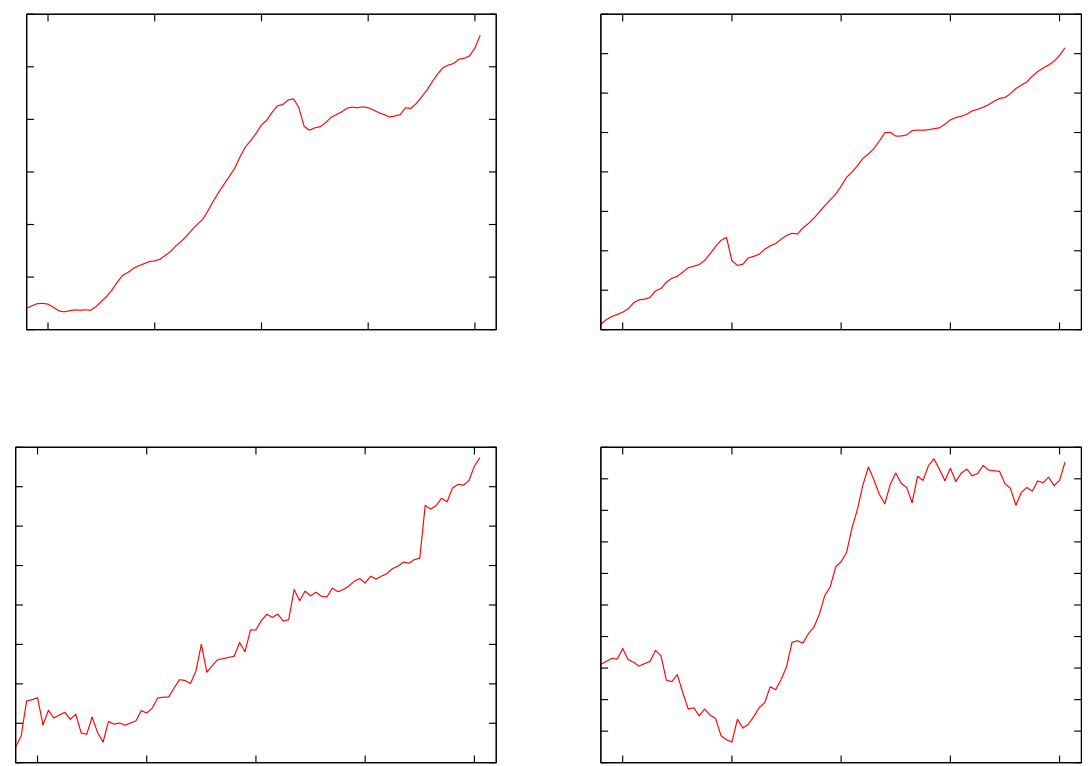

Figure 1. The Course of the Time Series' Development

Source: Authors' calculations in Gretl 1.9.4

On the basis of these results (see Table 4 and Table 5), we proceeded to the cointegration test. We conducted the cointegration test using the Engle-Granger test. For this test, it is necessary for the original time series to be nonstationary and to have the same order of integration.

Table 5

The Results of the Augmented ADF Test for a Unit Root - Second Difference

\begin{tabular}{|c|c|c|c|}
\hline Time series & Value of $p$ - parameter & Evaluation of ADF test results & $\mathrm{H}_{0}:$ \\
\hline d_d_l_GDP_CZE* & $5,944 \mathrm{e}-006$ & Time series stationary & Refused \\
\hline
\end{tabular}

d_d_1_GDP_CZE* is the result of ADF test for M3 and GDP.

Source: Authors' calculations in Gretl 1.9.4 
Figure 2 depicts the course of the first differences of the individual time series MB, GDP, M3, and loans in the CR after logarithmic transformation. Because we determined that the d_l_GDP_CZE time series were nonstationary in relation to $\mathrm{M} 3$ and $\mathrm{MB}$ even after differencing the variables, we proceeded to the second difference of the nonstationary time series' variables.
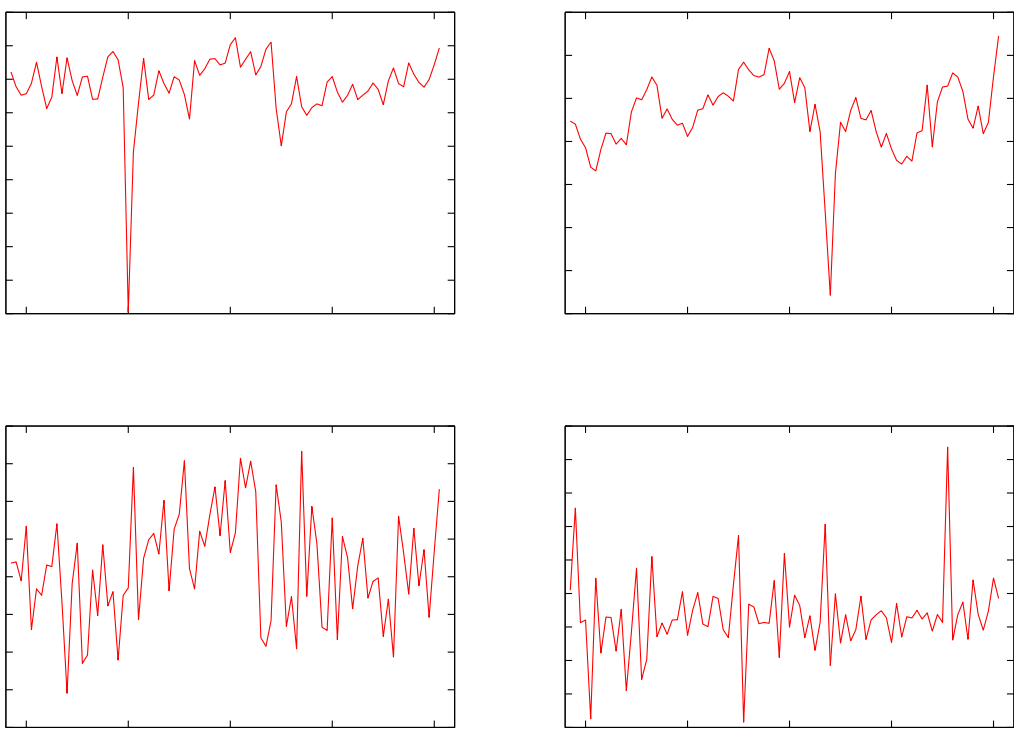

Figure 2. The Course of Development Time Series - First Difference Source: Authors' calculations in Gretl 1.9.4

\subsection{Cointegration Analysis - the Engle-Granger test}

Using the Engle-Granger test, we determined whether there was a relationship between the time series under examination. By comparing $p$-values at a 0.05 level of significance, we can subsequently decide whether the time series are cointegrated or not. Cointegration relationships can be active in both directions. Therefore, we have conducted the cointegration test for all the dependent and independent variables on each other reciprocally, i.e., for M3 as an independent variable and GDP as a dependent variable, as well as for M3 as a dependent variable and GDP as an independent variable. The results of the Engle-Granger test are depicted in Table 6, where the variable listed first indicates the dependent variable and the variable listed second indicates the independent variable.

From the $p$-values that were determined, which have values higher than the set level of significance $(\mathrm{p}>0,05)$, we can state that the time series 1_M3_CZE and 1_GDP_CZE as well as 1_GDP_CZE and 1_M3_CZE; 1_M3_CZE and 1_CRED_CZE as well as 1_CRED_M3 and 1_M3_CZE; and next 1_MB_CZE and 1_CRED_CZE as well as 1_CRED_CZE and 1_MB_CZE are not cointegrated, which means that there are no long-term relationships existing between them. In view of the results determined for the ADF test and the Engle-Granger cointegration test, we have continued to further determine the causal relationships via Granger causality, which does not assume the cointegration of the time series. 
Table 6

The results of the Engle - Granger Cointegration Test

\begin{tabular}{|l|c|c|c|}
\hline \multicolumn{1}{|c|}{ Time series } & Value of $p$ - parameter & $\mathrm{H}_{0}:$ & Evaluation of EG test results \\
\hline 1_M3_CZE/1_GDP_CZE & 0,6709 & Not refused & No cointegration \\
\hline 1_GDP_CZE/1_M3_CZE & 0,8409 & Not refused & No cointegration \\
\hline 1_M3_CZE/1_CRED_CZE & 0,6137 & Not refused & No cointegration \\
\hline 1_CRED_CZE/1_M3_CZE & 0,6013 & Not refused & No cointegration \\
\hline 1_MB_CZE/1_CRED_CZE & 0,8148 & Not refused & No cointegration \\
\hline 1_CRED_CZE/1_MB_CZE & 0,9085 & Not refused & No cointegration \\
\hline
\end{tabular}

Source: Authors' calculations in Gretl 1.9.4

\subsection{Granger causality test}

When testing for Granger causality, we test for the variables' influence in two directions, just as in the EG test. We have conducted testing using VAR models, where we use maximum possible time lag, i.e., a lag of six quarters. In Granger causality, we test the model with a constant or with a constant and a trend, depending on the results of testing for the optimal time lag, i.e., the minimum HQC value (4.1). The results of Granger causality for the variables M3, MB, GDP, and loans in the CR are depicted in Tables 7 and 8 . We have marked the significant coefficient for the relevant level of significance with a star $-0,01$ $\left(*^{* *}\right), 0,05\left(^{* *}\right)$, and $0,1\left(^{*}\right)$. In view of the results, only the $p$-values lower than 0,05 interest us (i.e., ** and $* * *)$.

On the basis of the calculations, we can state that, in the Czech Republic, the variable M3 has an effect on GDP at one lag according Granger's definition (Table 7).

Table 7

The Results of the The results of the Engel - Granger Cointegration Test for M3

\begin{tabular}{|c|c|c|c|c|c|c|c|}
\hline $\begin{array}{l}\text { M3_CZE/ } \\
\text { GDP_CZE }\end{array}$ & $\begin{array}{c}\text { Value of } \\
p- \\
\text { parameter }\end{array}$ & & $\mathrm{H}_{0}$ : & GDP_CZE/M3_CZE & $\begin{array}{c}\text { Value of } \\
p \text { - parameter }\end{array}$ & & $\mathrm{H}_{0}$ : \\
\hline d_1_GDP_CZE_1 & $1,2 \mathrm{E}-09$ & *** & Refused & d_1_M3_CZE_1 & 0,0009 & $* * *$ & Refused \\
\hline d_1_GDP_CZE_2 & 0,1719 & & Not refused & d_1_M3_CZE_2 & 0,4995 & & Not refused \\
\hline d_1_GDP_CZE_3 & 0,2923 & & Not refused & d_1_M3_CZE_3 & 0,4303 & & Not refused \\
\hline d_1_GDP_CZE_4 & 0,7455 & & Not refused & d_1_M3_CZE_4 & 0,3135 & & Not refused \\
\hline d_1_GDP_CZE_5 & 0,1105 & & Not refused & d_1_M3_CZE_5 & 0,8437 & & Not refused \\
\hline d_1_GDP_CZE_6 & 0,2511 & & Not refused & d_1_M3_CZE_6 & 0,6655 & & Not refused \\
\hline $\begin{array}{c}\text { M3_CZE/ } \\
\text { CRED_CZE }\end{array}$ & & & & $\begin{array}{c}\text { CRED_CZE/ } \\
\text { M3_CZE }\end{array}$ & & & \\
\hline d_1_CRED_CZE_1 & 0,4726 & & Not refused & d_1_M3_CZE_1 & 0,0008 & $* * *$ & Refused \\
\hline d_1_CRED_CZE_2 & 0,5077 & & Not refused & d_1_M3_CZE_2 & 0,5085 & & Not refused \\
\hline d_1_CRED_CZE_3 & 0,9377 & & Not refused & d_1_M3_CZE_3 & 0,4248 & & Not refused \\
\hline d_1_CRED_CZE_4 & 0,5021 & & Not refused & d_1_M3_CZE_4 & 0,3348 & & Not refused \\
\hline d_1_CRED_CZE_5 & 0,2465 & & Not refused & d_1_M3_CZE_5 & 0,8538 & & Not refused \\
\hline d_1_CRED_CZE_6 & 0,0235 & $* *$ & Refused & d_1_M3_CZE_6 & 0,7057 & & Not refused \\
\hline
\end{tabular}

Source: Authors' calculations in Gretl 1.9.4 
Using the M3 variable, we can improve the prediction of GDP's development in the CR by using one lag. On the other hand, we can state that GDP also has a causal effect on the M3 variable at one lag by Granger's definition; thus, using the variable GDP makes it possible to improve the prediction of M3's development with this lag. On the basis of the calculations, we can state that, by Granger's definition, the M3 variable affects loans at 6 lags for the Czech Republic. This means that we can improve prediction of the development of loans in the CR at the given time lag by using the M3 variable. On the other hand, we can state that loans have a causal effect on the M3 variable with 1 lag by Granger's definition, which makes it possible to predict M3's development using this time lag.

Table 8

The Results of the The results of the Engel- Granger Cointegration Test for MB

\begin{tabular}{|c|c|c|c|c|c|c|c|}
\hline $\begin{array}{l}\text { MB_CZE/ } \\
\text { CRED_CZE }\end{array}$ & $\begin{array}{c}\text { Value of } \\
p- \\
\text { parameter }\end{array}$ & & $\mathrm{H}_{0}:$ & $\begin{array}{c}\text { CRED_CZE/ } \\
\text { MB_CZE }\end{array}$ & $\begin{array}{c}\text { Value of } \\
p \text { - parameter }\end{array}$ & & $\mathrm{H}_{0}:$ \\
\hline d_l_CRED_CZE_1 & 0,3288 & & Not refused & d_l_MB_CZE_1 & 0,0032 & *** & Refused \\
\hline d_1_CRED_CZE_2 & 0,6377 & & Not refused & d_1_MB_CZE_2 & 0,2716 & & Not refused \\
\hline d_1_CRED_CZE_3 & 0,792 & & Not refused & d_1_MB_CZE_3 & 0,4724 & & Not refused \\
\hline d_l_CRED_CZE_4 & 0,5728 & & Not refused & d_1_MB_CZE_4 & 0,5144 & & Not refused \\
\hline d_1_CRED_CZE_5 & 0,3062 & & Not refused & d_1_MB_CZE_5 & 0,4799 & & Not refused \\
\hline d_l_CRED_CZE_6 & 0,0205 & ** & Refused & d_1_MB_CZE_6 & 0,7039 & & Not refused \\
\hline
\end{tabular}

Source: Authors' calculations in Gretl 1.9.4

On the basis of the calculations, we can state that for the Czech Republic, the variable of MB affects GDP at 1 lag using Granger's definition. This means that we can improve prediction of GDP's development in the $\mathrm{CR}$ at this considered lag using the variable of MB (Table 8).

\section{DISCUSSION}

The issues surrounding money's exogeneity and monetary policy that is conducted by targeting money aggregates have primarily been dealt with by monetarists. Inflation targeting, central banks' present day monetary policy regime, works with the mechanism of transmission differently when compared with money supply targeting, the monetary policy regime formerly used by central banks. A central bank cannot target the money supply and conduct inflation targeting at the same time. The money supply is understood to be an endogenous variable if the central bank uses inflation targeting as its monetary policy regime. When there is inflation targeting, monetary aggregates are understood to be a consequence of the behavior of central banks and commercial banks. Currently, many central banks around the world are using the inflation targeting regime, including the European Central Bank, the Czech National Bank or the Federal Reserve System.

On the basis of the analyses conducted here, we can state that the money supply can be considered endogenous, regardless of the CNB's monetary policy regime from 1996 to 2017. The empirical results are in line with the post-Keynesian theory of an endogenous money supply, which is proven by two-way Granger causality between loans and both the monetary base and the money supply as well as between GDP and the money supply and the money supply and loans. Empirical results show that the money supply in the CR is in agreement with the concept of an endogenous money supply from the structuralist and liquidity preference perspectives. One-way causality, according to the accommodationist concept, was not confirmed for the causal relationships that were examined. On the basis of studies by other authors, it 
is clear that other countries also have an endogenous money supply (Table 2). However, there is variation in the endogenous concept of the money supply among the countries listed, which is determined by the structure of individual economies, the specific conditions in individual countries, and the time periods for which the testing was conducted.

\section{CONCLUSIONS}

In this paper, we have focused on determining the endogeneity of money in the Czech Republic. We used quarterly data for the period starting with the $1^{\text {st }}$ quarter of 1996 through to the $2^{\text {nd }}$ quarter of 2017 for the time series analysis. On the base of this analysis, we came to the conclusion that the time series examined are not cointegrated. Therefore, no long-term relationships exist between the variables monitored, i.e., between the M3 monetary aggregate and both GDP and loans as well as between the money base and loans. According to theoretical evaluation of money's endogeneity and the analyses that were conducted, we can state that the money supply, expressed using the M3 monetary aggregate, and the money base were endogenous in nature for the Czech Republic during the period that was observed.

The concept of a structuralist endogenous money supply corresponds with the current approach of the CNB's monetary policy, which is conducted using interest rates and not money supply targeting. Thus, the CNB does not control the money supply but rather influences the Czech economy via interest rates. Confirming the liquidity preference version of an endogenous money supply means that the deposit offering, which is created by new bank loans, does not necessarily need to be maintained by the new deposit owners, who have an independent liquidity preference concerning the deposit amounts they would like to maintain. This can lead to a situation where an independent demand for money limits the ability of loans to create further deposits in the Czech economy. All central banks that use inflation targeting as their monetary regime assume an endogenous concept of money supply. In further research, we can focus on verifying the endogenity of money in the euro area.

\section{ACKNOWLEDGEMENT}

The paper has been created with the financial support of The Czech Science Foundation (project GACR No. 17-02509S - Emerging financial risks during a global low interest rate environment).

\section{REFERENCES}

Adamowicz, M., \& Machla, A. (2016). Small and Medium Enterprises and the Support Policy of Local Government. Oeconomia Copernicana, 7(3), 405-437. doi: http://dx.doi.org/10.12775/OeC.2016.024

Ahmad, N., \& Ahmed, F. (2006). The long-run and short-run endogeneity of money supply in Pakistan: An empirical investigation. SBP Research Bulletin, 2(1), 267-278. Retrieved from: https://s3.amazonaws.com/academia .edu.documents/36080204/LongRun_Short_Run_Endogeneity_of_Money_Supply.pdf?AWSAccess KeyId =AKIAIWOWYYGZ2Y53UL3A\&Expires=1524665961\&Signature=ZKYnv3ptoNXIHIeg $\% 2$ FnmpK My9oJM\%3D\&response-contentdisposition=inline $\% 3 \mathrm{~B} \% 20$ ilename $\% 3 \mathrm{DThe}$ Long-run_and_Shortrun Endogeneity_o.pdf

Atkinson, A.B., \& Stiglitz, J.E. (1980). Lectures on Public Economics. London, McGraw Hill.

Ayyagari, M., Beck, T., \& Demirguc-kunt, A. (2007). Small and medium enterprises across the globe. Small Business Economics, 29, 415-434. doi: http://dx.doi.org/10.1596/1813-9450-3127

Badarudin, Z. E., Khalid, A., M.., \& Ariff, M.. (2012). Exogenous or endogenous money supply: Evidence from Australia. The Singapore Economic Review, 57(04), 1-12. doi: 10.1142/S0217590812500257

Bank for International Settlements (2017). Credit to the non-financial sector. Retrieved from: https://www.bis.org/statistics/totcredit.htm?m =6\%7C380\%7C669 
Borio, C. EV. (1997). Monetary policy operating procedures in industrial countries. BIS Working Paper, 29. doi: http:/ /dx.doi.org/10.2139/ssrn.860627

Černohorský, J. (2017). Types of bank loans and their impact on economic development: a case study of the Czech republic. E+ M Ekonomie a Management, 20(4), 34-48. doi: http://dx.doi.org/10.15240/tul/001/2017-4-003

Engle, R., F. \& Granger, C.W.J. (1987). Co-Integration and Error Correction: Representation, Estimation, and Testing. Econometrica, 55(2), 251-276. Retrieved from: http://www.ntuzov.com/Nik_Sit e/Niksfiles/Research/ papers /stat_arb/EG_1987.pdf

Eurostat. (2017a). Harmonized Index of Consumer Prices: All Items for Each Republic. Retrieved from: http:/ /ec.europa.eu/eurostat/web/products-datasets/-/teicp230.

Eurostat (2017b). Real Gross Domestic Product for EAch Republic. Retrieved from: http://ec.europa.eu/eurostat/ web/national-accounts/data/database

Fontana, G. (2002). The making of monetary policy in endogenous money theory: an introduction. Journal of Post Keynesian Economics, 24(4), 503-509. doi: https://doi.org/10.1080/01603477.2002

Gottschalk, J., Van Zandweghe, W. \& Martinez Rico, F. (2000). Money as an Indicator in the Euro Zone. Kiel Working Paper. Retrieved from: https://www.econstor.eu/bitstream/10419/17918/1/kap 984.pdf

Granger, C.W.J. (1969) Investigating causal relations by econometric models and cross-spectral methods. Econometrica: Journal of the Econometric Society, 37(3), 424-438. doi: https://doi.org/10.2307/1912791

Granger, C.W.J. (1981). Some properties of time series data and their use in econometric model specification. Journal of Econometrics, 16(1), 121-130. doi: https://doi.org/10.1016/0304-4076(81)90079-8

Granger, C.W.J. \& Newbold, P. (1974). Spurious regressions in econometrics. Journal of econometrics, 2(2), 111-120. doi: https://doi.org/10.1016/0304-4076(74)90034-7

Hannah, E.J. \& Quinn, B.G. (1979). The determination of the order of an autoregression. Journal of the Royal Statistical Society. Series B (Methodological), 41(2), 190-195. Retrieved from: http://www.jstor.org/stable/2985032?seq=1\# page_scan_tab_contents

Haghight, J. (2011). Endogenous and Exogenous Money: an empirical investigation from Iran. Journal of Accounting, 1(1), 61-76. Retrieved from: http://wbiaus.org/5.\%20Jafar.pdf

Howells, P. (1997). The demand for endogenous money: a rejoinder. Journal of Post Keynesian Economics, 19(3), 429-435. doi: 10.1080/01603477.1997.11490120

Howells, P. \& Bain, K. (2009.) Monetary economics: policy and its theoretical basis. London: Palgrave Macmillan.

Hušek, R. (2007). Ekonometrická analýza. Praha: Oeconomica.

Chick, V. \& Dow, S. (2002). Monetary policy with endogenous money and liquidity preference: a nondualistic treatment. Journal of Post Keynesian Economics, 24(4), 587-607. doi: https://doi.org/10.1080/01603477.2002.11 490345

Kaldor, N. (1970). The New Monetarism. Lloyds Bank Review, 97,1-17. Retrieved from: http://public.econ.duke.edu/ kdh9/Courses/Graduate \%20Macro\%20History/Readings-1/Kaldor.pdf

Koderová, J., Sojka, M. \& Havel, J. (2008). Teorie peněz. Praha: ASPI.

Liew, V. K.-S. (2004). Which Lag Length Selection Criteria Should We Employ? Economics Bulletin, 3(33), 1-9. Retrieved from:http://ssrn.com/abstract $=885505$

Moore,B. J. (1998). Accommodation to accommodationism: a note. Journal of Post Keynesian Economics, 21(1), 175-178. doi: 10.1080/01603477.1998.11490187

Nayan, S., Kadir, N., Abdullah, M. S., \& Ahamad, M. (2013). Post Keynesian endogeneity of money supply: Panel evidence. Procedia Economics and Finance, 7, 48-54. doi: 10.1016/S2212-5671(13)00217-7

OECD. (2017). Broad money (M3) (indicator). Retrieved from: http://www.oecd-ilibrary.org/content/indicator/ $1036 \mathrm{a} 2 \mathrm{cf}-\mathrm{en}$

Palley, T. I. (1996). Accommodationism versus structuralism: time for an accommodation. Journal of Post Keynesian Economics, 18(4), 585-594. doi: 10.1080/01603477.1996.11490088

Palley, T. I. (1994). Competing views of the money supply process: theory and evidence. Metroeconomica, 45(1), 67-88. doi: 10.1111/j.1467-999X.1994.tb00013.x

Palley, T. I. (1991). The endogenous money supply: consensus and disagreement. Journal of Post Keynesian Economics, 13(3), 397-403. doi: 10.1080/01603477.1991.11489856 
Pollin, R. (1991). Two theories of money supply endogeneity: some empirical evidence. Journal of Post Keynesian Economics, 13(3), 366-396. doi: 10.1080/01603477.1991.11489855

Shanmugam, B., Nair, M., \& Li, O. W. (2003) The endogenous money hypothesis: empirical evidence from Malaysia (1985-2000). Journal of Post Keynesian Economics, 25(4), 599-611. Retrieved from:: https://www. tandfonline.com/doi/ abs/10.1080/01603477.2003.11051378

Sims, C. A. (1972). Money, income, and causality. The American economic review, 62(4), 540-552. Retrieved from: http://www.jstor.org/stable/1806097?seq=1\#page_scan_tab_contents

Vera, A. P. (2001) The endogenous money hypothesis: some evidence from Spain (1987-1998). Journal of Post Keynesian Economics, 23(3), 509-526. DOI 10.1080/01603477.2001.11490296 